\title{
The Unexpected Dynamics of Politicisation of Migration: The Case of the Refugee Crisis in Sicily
}

\section{Andrea Pettrachin*}

Migration Policy Centre, European University Institute, Florence, Italy and Department of Politics, University of Sheffield, Sheffield, UK

*andrea.pettrachin@eui.eu

ORCID ID: https://orcid.org/0000-0001-7238-9631.

This research has been funded by: European Research Council (ERC), European Union's Seven Framework Programme (FP-7/2007-2013), Grant Agreement No 340430 ('Prospects for International Migration Governance') awarded to Professor Andrew Geddes.

No conflict of interest.

Acknowledgements: The author would like to thank Professor Andrew Geddes and the three anonymous reviewers, whose comments have contributed to improve this manuscript.

The Version of record of this manuscript has been published and is available in MEDITERRANEAN POLITICS 14 Apr 2020

https://www.tandfonline.com/10.1080/13629395.2020.1741294 


\title{
The Unexpected Dynamics of Politicisation of Migration: The Case of the Refugee Crisis in Sicily
}

\author{
Abstract (100 words): Through analysis of decision-making dynamics on \\ migration in Sicily, this paper shows how party elites define strategies to \\ politicise migration. Conventional explanations of the politicisation of migration \\ assume that party elites politicise migration in reaction to increasing flows and \\ issue salience, explicitly ignoring cognitive factors and actors' reasoning. \\ Conversely, I show that Sicilian party elites' politicisation strategies are not \\ shaped by objective evidence about public attitudes, salience and the effects of \\ migration, but, rather, by actors' understandings of these objective factors, \\ embedded in deeply rooted narratives and reinforced by the outputs of the \\ decision-making dynamics that they contribute to shape.
}

Keywords: politicisation, migration, decision-making, refugee_crisis, Italy.

\section{Introduction}

This paper shows the unexpected dynamics of politicisation of migration in Sicily, a region of Europe which was centrally affected by the refugee crisis but where objective events and incidents such as high migration flows, high issue salience and anti-migrant public attitudes did not lead to high levels of politicisation of the issue. By attempting to explain these dynamics, the paper aims to contribute to the debate on the drivers of party actors' politicisation strategies (Odmalm \& Bale, 2015, p.369), with a specific focus on the regional level, showing that cognitive frames and their influence on strategic decisions are a crucial but missing part of the puzzle.

The politicisation of migration - i.e. the expansion of 'the scope of conflict' on migration within a political system (Grande, Schwarzbözl and Fatke 2018, p. 3) - has 
been extensively analysed in Europe, before and after the recent refugee crisis ${ }^{1}$. Many scholars, in particular, have tried to identify the key actors that contribute to influence the level of politicisation of migration within political systems, mostly concluding that political parties, through their actions and claims, play a decisive role in these dynamics (Meyer \& Rosenberger, 2015; Hobolt \& De Vries, 2015). Building on this key finding, other scholars have tried to identify the key factors that drive party actors' 'politicisation strategies' at both the national and subnational levels. They did so, mainly, by examining correlations between the number and type of immigration-related claims made by party actors and several objective factors such as migration patterns, issue salience ${ }^{2}$, public attitudes to immigration and issue entrepreneurship of right-wing parties (Hepburn, 2014; Grande, Schwarzbözl \& Fatke, 2018; Van der Brug, D’Amato, Ruedin, \& Berkhout, 2015).

This article aims to contribute to this debate on the drivers of party politicisation strategies, complementing the existing literature, by focusing specifically on party actors' understandings of the effects of migration flows and the decision-making processes that produce politicisation strategies. These elements have been largely neglected by scholars, who mostly tend to extrapolate mere assumptions about the

${ }^{1}$ The term 'politicisation' is variously defined in the existing literature, for a review see: Grande, Schwarzbözl \& Fatke, 2018.

${ }^{2}$ Krosnick (1990, p. 60) defines issue salience as 'the degree to which a person is passionately concerned about and personally invested in an attitude' (for a more extensive review of the concept, see Dennison, 2019). Issue salience is typically measured in surveys by asking respondents what they consider to be the (two) most important issues or problems affecting themselves or their country (Dennison \& Geddes, 2018, p.5). 
reasoning of party actors and how they make sense of migration and its effects, arguing that cognitive factors are not relevant in party actors' decisions about their politicisation strategies (Abou-Chadi \& Helbling, 2018, p. 700). While it is undeniable that immigration has been increasingly politicised within local and national political systems in times of high migration flows, high issue salience and in the presence of strong radical right parties, I argue that this approach has some potential limitations. Eminent scholarly works (Cohen, March \& Olsen, 1972; Brunsson, 1985; Kingdon, 2014) have indeed illustrated potential decoupling of thought and actions, and of problems and choices, during the decision-making process, showing that the emergence and enactment of understandings is not always a straightforward process.

This article therefore develops an approach which focuses on both the outputs of party actors' politicisation strategies and the decision-making processes that produce them. I apply this two-step approach to the powerful and counter-intuitive case of Sicily, an Italian region that has been centrally affected by the refugee crisis and after 2015 was characterised by high issue salience and widespread anti-migrant attitudes. In the first part of the paper I ask: was the Sicilian political system characterised by high or low levels of politicisation of migration during the refugee crisis, and which party actors adopted proactive politicisation strategies? To answer this question I analyse local party manifestoes, media interviews released by party actors ${ }^{3}$ and policy documents. The paper shows that, contrary to the expectations, Sicily experienced very low levels of politicisation of migration. Most party actors competing at local, regional and national

\footnotetext{
${ }^{3}$ In this article I use the term 'local political elite' to refer to party actors within the Sicilian political system. The term is meant to refer to mayors, members of local and regional governments, national and regional MPs and the main party leaders (see Cochrane 1998).
} 
elections, including radical right and centre-right party actors, did not adopt proactive politicisation strategies. Only mayors of the main cities unexpectedly did so, but framing migration in very positive terms.

In the second part of the paper, to account for these unexpected findings, I analyse decision-making processes by party actors that produced their politicisation strategies. I do so, through the adoption of an actor-centred constructivist perspective which applies insights from framing theories and sensemaking approaches, assuming that actors' decisions in situations of crisis are mostly driven by their understandings of the effects of migration (Pierre, 2000). I therefore address a second and third research questions: how did party actors at the regional level understand the effects of migration flows and public reactions to such flows? And how did these subjective understandings shape or influence party actors' politicisation strategies? To answer these questions I conducted 27 semi-structured interviews with Sicilian party actors.

The analysis leads to three main findings. First, the Sicilian case shows that it is not self-evident that increase in migration flows and high issue salience initiate reactive responses by party elites, leading to high levels of politicisation of migration (potential decoupling of problems and solutions). Second, Sicilian party elites' decisions to politicise (or not) immigration are not shaped by objective evidence about public attitudes but, rather, by their understandings of the effects of immigration on underlying social systems. These understandings are formed through a process of sensemaking that is influenced by the events and cues that actors pick up from their environment, past experiences, identity processes, social relations (potential decoupling of evidence and understandings). Third, these understandings are embedded in narratives, influenced by inherited traditions (Bevir \& Rhodes, 2008, p. 171), and reinforced by the outputs of the 
very decision-making dynamics that they contribute to shape (sensemaking is enactive of sensible environments).

The paper is organized as follows. It begins by developing the theoretical approach and conceptual claims. It then justifies case selection illustrating why Sicily is a puzzling and revealing case. This is then followed by a section that shows migration not to be the object of proactive politicisation strategies by most Sicilian party actors, despite objective indicators suggesting that it should be. The subsequent section uses material from 27 semi-structured interviews conducted in 2018 to unpick decisionmaking processes, to show how meanings are constitutive of the actions/inactions of Sicilian political actors, and to illustrate the drivers of these unexpected politicisation strategies.

\section{Opening the 'black box' of party politicisation strategies}

Several scholarly works have emphasised that political parties play a decisive role in the emergence of political conflicts on immigration (Meyer \& Rosenberger, 2015; Hobolt \& De Vries, 2015). While it is often assumed that immigration issues tend to be most successfully mobilised by non-governing radical right parties (Grande, Schwarzbözl \& Fatke, 2018), many recent contributions argue that the politicisation of immigration at both the national and subnational levels is driven by mainstream parties, mostly from the centre-right (Van der Brug, D’Amato, Ruedin, \& Berkhout, 2015, p. 195; Bale, 2008; Green-Pedersen \& Krogstrup, 2008; Hepburn, 2014; Meyer \& Rosenberger, 2015).

Many scholars have therefore tried to identify the drivers of political parties' politicisation strategies (and positioning on migration more broadly). Most of them 
focused on visible and measurable factors such as migration patterns and socioeconomic variables (Green-Pedersen \& Otjes, 2017; Van der Brug, D’Amato, Ruedin, \& Berkhout, 2015), public attitudes to immigration and issue salience (Gilligan, 2015; Castelli Gattinara, 2016), and issue entrepreneurship by radical right parties (Hobolt \& De Vries, 2015; Meyer \& Rosenberger, 2015; Grande, Schwarzbözl \& Fatke, 2018). Assuming that opportunities and constraints at the subnational level partially differ from those in play at the national level, Hepburn (2014), Zapata-Barrero (2009) and Castelli Gattinara (2016) specifically identified factors at the local or regional levels that tend to influence party actors' decisions to politicise the immigration issue. These include: socio-economic factors such as high migration flows and high unemployment rates; high issue salience; political factors such as proportional or mixed-member electoral systems, high political variation and the presence of electorally successful antiimmigration parties; extensive competences over immigration policies by regional and local governments; focusing events and media.

Decision-making processes by party actors at both the national and subnational levels and their understandings are largely neglected in this literature. Scholars often tend to extrapolate mere assumptions about the reasoning of political actors, under the conviction that cognitive factors are not relevant in party actors' decisions about their politicisation strategies and positioning on immigration (Abou-Chadi and Helbling, 2018, p. 700). Therefore, following an increase in migration flows and issue salience, radical right parties are generally assumed to adopt issue entrepreneurship strategies to increase their consensus (Dennison and Geddes, 2018, p.6). Mainstream centre-right and centre-left parties usually have incentives to downplay or ignore immigration as an electoral priority, since this tends to cause ideological splits and intra-party 
fragmentation, but, when facing increasing migration flows, public concerns and issue salience and/or the pressure from the radical right, they are assumed to modify their positions contributing to politicise migration, 'whether they like it or not' (Abou-Chadi and Helbling, 2018, p. 700; Bale, 2008; Gianfreda, 2017; Odmalm and Bale, 2015; Vranceanu, 2017). Mismatches between mainstream party approaches and their electorate's preferences are sometimes observed, but these are assumed to be unlikely in situations of high issue salience (Abou-Chadi and Helbling, 2018; Odmalm \& Bale 2015, p. 366).

Despite these considerations being evidently plausible, I argue that making assumptions about the nature of a process by extrapolating back from its outputs is analytically and methodologically problematic. Brunsson (1985) showed the scope for the presence of complex and contradictory pressures in decision-making processes, due to both material and ideational factors, to which parties must try to respond and that are not necessarily evident in their outcome. Particularly in situations of crisis, actors' interpretations of the effects of external environments powerfully drive decision-making preferences (Pierre, 2000), often leading to the decoupling of problems and choices (Cohen, March \& Olsen, 1972). Furthermore, eminent political scientists have shown that party elites can manipulate the salience of issues for strategic reasons (see Iversen \& Goplerud, 2018; Marks \& Steenbergen, 2004, p. 166).

This article focuses on this 'missing middle' to shed light on how party actors' understandings of the effects of migration flows are formed, and how they influence their politicisation strategies. It thus reverses the analytical focus of the existing literature and, rather than merely examining outputs (e.g. the migration-related claims or actions made), it also focuses on decision-making processes that produce them. To do 
so, I adopt a constructivist actor-centred perspective focused on actors' understand ings and the social and political context in which actors operate, which is assumed to influence how understandings are processed to shape actions (Bevir \& Rhodes, 2003, p. 4). I therefore assume that actors are both 'situated agents' (ibid.) - whose cognitive understandings and context for action are shaped by social, historical, political and organisational settings - and 'strategic actors', who can influence the context in which they operate with their decisions (Hay, 2002, p. 128).

To investigate the cognitive micro-foundations of actors' strategies and decisions, I draw concepts and ideas from the framing perspective and the sensemaking approach, two largely separate literatures that have addressed the cognitive process by which meanings of events are constructed and translated into action. While framing theories are often applied in political science, the literature mostly examines frames as devices embedded in political discourse - 'frames in communication' - rather than as internal structures of the mind - 'frames in thought' (Scheufele, 1999, p. 106). This article investigates both dimensions but specifically focuses on the much less explored 'micro' cognitive dimension of the framing process, to extrapolate the set of dimensions that drive individuals' understanding of events. Such analysis is complemented by insights from the sensemaking approach, mostly developed in organizational studies (Weick, 1995). Sensemaking emphasizes the social psychological and epistemological processes by which actors develop some sort of sense regarding what they are up against, what their own position is relative to what they sense, and what they need to do (Helms Mills Thurlow \& Mills, 2010, p. 183). It allows to understand how 'frames in thought' are enacted and inform strategies. Following Bird and Osland (2005, p. 125), sensemaking can be conceptualised as an ongoing process involving an iterative cycle of three steps during which actors have to answer three main questions: (1) framing the 
situation ('what is going on around us?'); (2) making attributions about this situation ('what should we do next?'), and (3) selecting a script that, based on the frames and attributions adopted, guides actions ('which strategy can we adopt?'). Applying framing and sensemaking approaches together allows to shed light on the question of how understandings about the effects of migration flows are formed and acted upon, and then influence party actors' politicisation strategies.

\section{Case Selection and Methods}

The approach developed is applied to the case of Sicily, a powerful 'heuristic case' (Eckstein, 1973), which allows to illustrate the value of the broader conceptual and methodological claim.

This Italian region represents a highly puzzling case. Traditionally, Sicilian politicians did not show any inclination to exploit anti-migrant fears for electoral gain (Cole, 1997, p. 124) and until 2014 immigration was not a prevailing concern on the Sicilian regional agenda (Bassi, 2014, p. 60). However, five main factors, linked to findings of the existing literature cited above, would suggest the emergence of high levels of politicisation of immigration and proactive politicisation strategies by party actors (especially those affiliated to right-wing parties) in election debates during the refugee crisis in Sicily.

First, the region was highly exposed to migration flows, as Sicilian harbours became, in 2015, the main European 'gateway' for asylum-seeking migration. Since then, Sicily hosted the highest number of asylum-seekers in Italy (Ministry of Interior, 2018), dispersed in reception centres throughout a region characterised by high unemployment and a stagnant economy harshly hit by the economic crisis. In 2017, more than 5,000 asylum-seekers were hosted in the 'CARA di Mineo', a huge reception 
centre in a village close to Catania. The national leaders of the main Italian right-wing parties repeatedly stated during the refugee crisis that Sicily itself had become 'the EU's reception centre' (AskaNews, 2017; Ansa, 2018) ${ }^{4}$.

Second, Flash Eurobarometer data (Figure 1) suggest that during the refugee crisis the salience of migration in Sicily was significantly high: 37 per cent of Sicilian respondents mentioned immigration as their first issue of concern in 2015, 23 per cent in 2018 (more than in most of the other Italian regions). Furthermore, many scandals around the management of Sicilian reception centres, often conceived as profit-driven businesses, and the infiltration of the organized crime in the reception system received wide coverage in local and national media (D’Angelo 2019, p. 2214; Manzano, Mishtal \& Harris, 2018, p. 83).

Third, available data also suggest the prevalence of negative attitudes towards non-EU migrants in Sicily since before the refugee crisis, and that these attitudes became more negative during the crisis (Figure 2). Moreover, 'contrary to common perceptions that northern Italians are more anti-immigration than southern Italians' (Dixon et al. 2018, p. 80) both Eurobarometer and IPSOS data show that sentiments towards non-EU migrants are more negative in Sicily than in Central and Northern Italy (Genovese, Belgioioso \& Kern 2016, p. 9; Dennison, 2018).

\footnotetext{
${ }^{4}$ Furthermore, whilst in the past Southern Italy was mainly a pass-by area for migrants, the number of foreign residents in Sicily significantly increased in the last decade (Mastoianni, 2018), during which the agriculture sector increasingly became 'a pull factor for irregular migration’ (Corrado et al., 2018).
} 
Figure 1. Salience of Immigration in Italian Regions, 2012-2018 (source: Flash

Eurobarometer).

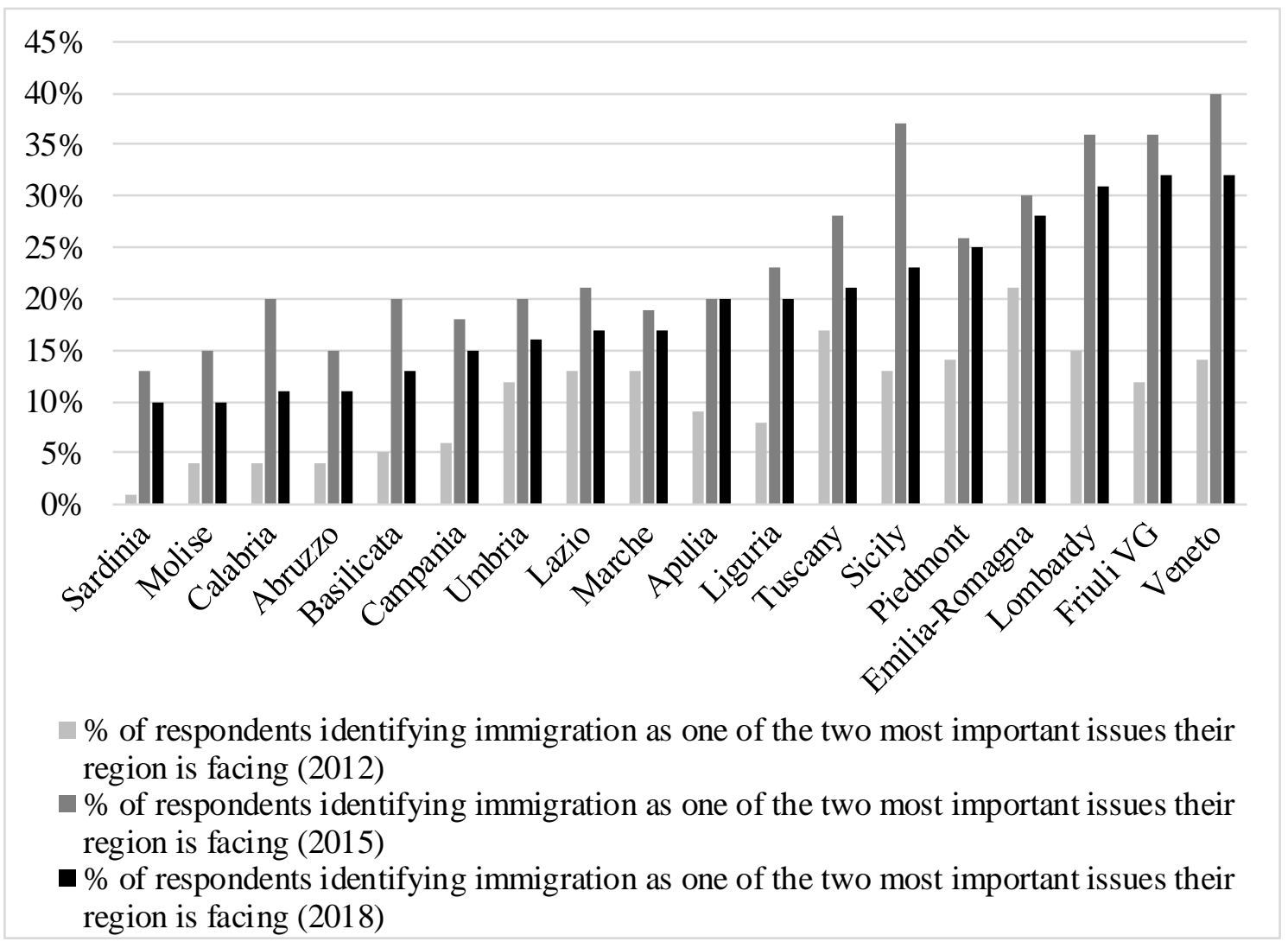

Figure 2. Average attitudes toward immigration in Sicily. Higher numbers mean more positive attitudes (Source: European Social Survey 2012-2016, 324 respondents).

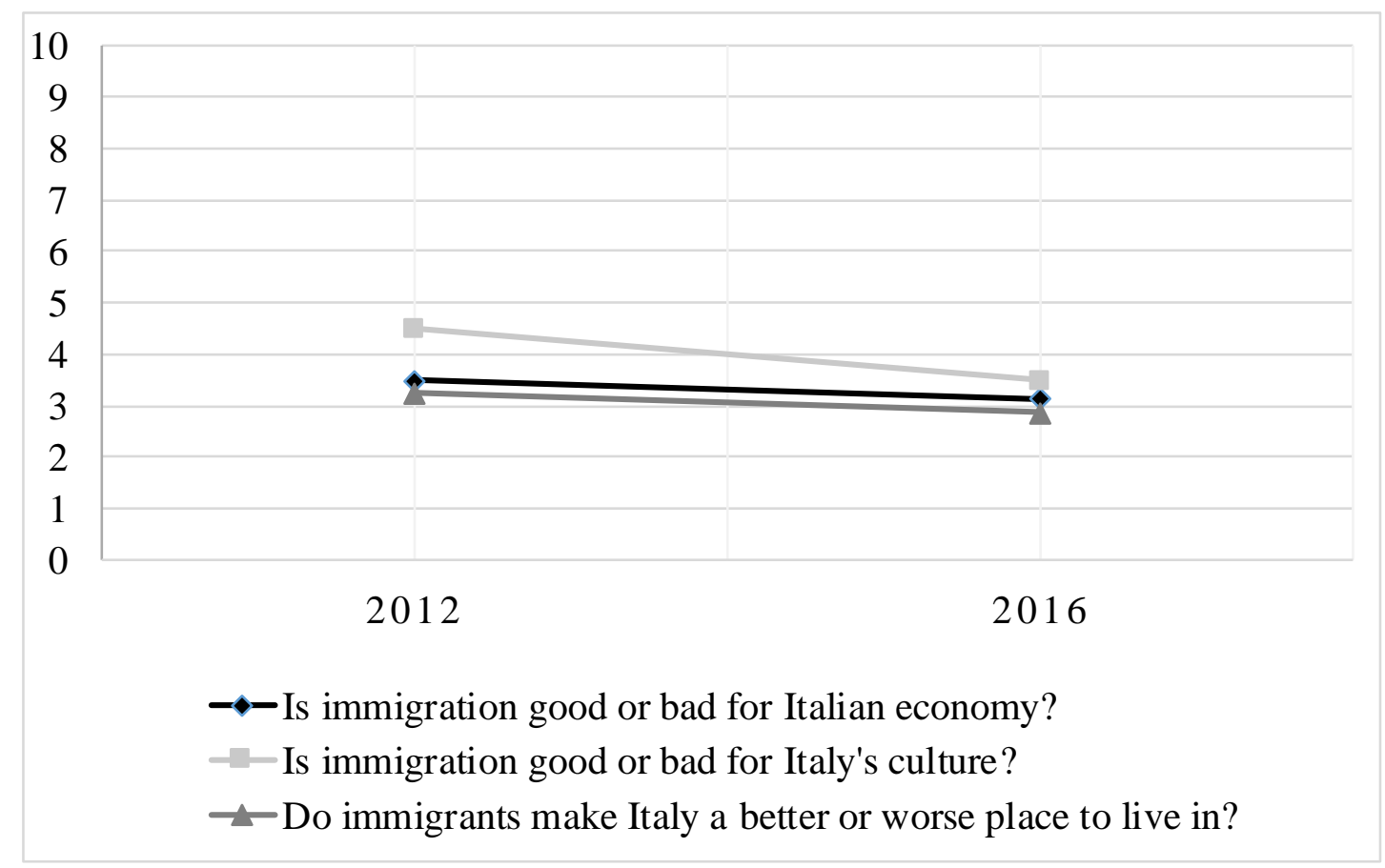


Fourth, several political factors suggest the potential for the adoption by parties of strategies of issue-differentiation and politicisation of migration. These include the local and regional electoral systems, the high political variation, and the presence of a deeply rooted anti-immigration party, the radical right post-fascist Fratelli d'Italia (FdI) (De Giorgi \& Tronconi, 2018, p. 338). After 2011 Sicily was characterized by both extreme electoral volatility over time and a significant instability of preferences in elections of different types (Cerruto \& Raniolo, 2018). Since 2012, the populist Movimento Cinque Stelle (M5S) has been the leading party at all national elections (Ivaldi et al, 2017). Several mayors are not affiliated to national parties (Figure 3), a sign of the personalisation of local Sicilian politics. The regional government was controlled by a centre-left coalition led by the Partito Democratico (PD) and, after 2017, by a centre-right coalition, with a strong radical right component, including FdI and the Lega, which recently started to gain some consensus in Sicily after Matteo Salvini got rid of its traditional anti-southernism.

Figure 3. Political Affiliation of Sicilian Mayors in late 2017 (source: www.comuniverso.it).

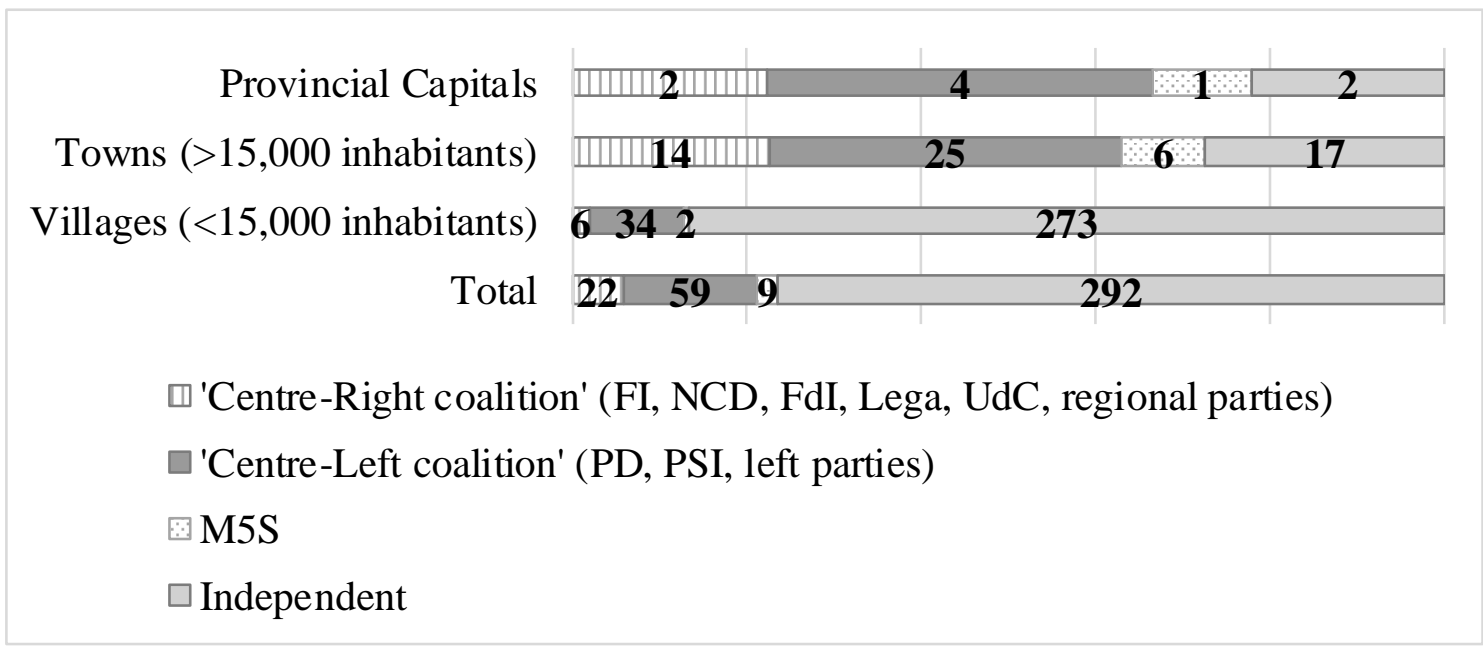


Finally, regional and local governments have significant competences in the field of migrants' integration, asylum-seekers' reception, and in other fields connected to migration in political rhetoric (Castelli Gattinara, 2016). Since before the refugee crisis, the immigration issue had penetrated local political debates in Italy (Caponio, 2005) and is now 'established in local electoral campaign dynamics', during which local political actors often try to 'exploit the symbolic power of immigration politics' debating issues in areas beyond their administrative competences (Castelli Gattinara, 2016, p. 2-4; Ambrosini, 2018).

These considerations suggest the potential for high levels of politicisation of the migration issue in Sicilian election debates. Following the existing literature, it is expected that right-wing party actors adopt issue entrepreneurship strategies and mobilise the issue during electoral campaigns. Centre-right party actors are also expected to adopt proactive politicisation strategies (and more restrictive positions on migration), while actors affiliated to centre-left parties and the M5S are expected to adopt issue avoidance strategies ${ }^{5}$.

To test these expectations, the next section analyses the migration-related claims and actions made by Sicilian party actors competing in local, regional and national elections held between November 2017 and June 2018. It does so, by examining electoral manifestoes, assuming that these provide reliable insights on strategic efforts to politicise immigration issues in an election - a common methodological strategy

\footnotetext{
${ }^{5}$ At the national level, party positions on immigration of the main Italian parties (PD, M5S,
} Forza Italia) became more restrictive between 2012 and 2017 (Dennison \& Geddes, 2019). 
adopted in the literature (Grande, Schwarzbözl \& Fatke, 2018; Castelli Gattinara, 2016). To complement these findings, I have analysed media interviews released by the main Sicilian party leaders between May 2017 and September 2018 (the period includes the electoral campaign for the national elections), found through a keyword search of online archives of local, national and international newspapers. Additional insights have been derived from 14 expert interviews (Dorussen, Lenz \& Blavoukos, 2005) conducted with actors that, because of their involvement in migration governance processes, had indepth knowledge of the Sicilian political debate on migration (Table 4 in the Annex).

The final sections of this article, then, investigates how party-actors' understandings and sensemaking processes influenced their politicisation strategies. To analyse decision-making processes, I have conducted 27 semi-structured interviews in May 2018 with party-actors from across the whole political spectrum (Table 5 in the Annex), in six provinces, across three geographical areas (North-East; South-East; West). Following the principles of 'quota sampling', interviewees have been chosen through careful consideration of several variables, including: institutional role, political affiliation, geographical area, type of municipality (provincial capital, town or village), type of reception centres hosted in the municipality. The sample includes party actors belonging to the 4 main party coalitions: 8 interviewees from the 'centre-right coalition' (Forza Italia, FdI, Lega, others); 5 from the 'centre-left coalition'; 7 actors affiliated to the M5S; 7 independent actors.

\section{The Diverse Dynamics of Politicisation of Migration in Sicily}

This section shows that Sicilian party-actors did not politicise the immigration issue in line with the expectations. Most party actors, including radical right party members, did not politicise immigration during electoral campaigns and publicly avoided the issue, while instead the mayors of the main cities, from across the whole political spectrum, 
politicised the issue proposing pro-migrant narratives.

To reach this conclusion, I derive insights from a content analysis of manifestoes of mayoral candidates at the local elections held in June 2018 in 14 Sicilian municipalities $^{6}$ (Table 1), and of presidential candidates at the regional elections held in November 2017 (Table 2). Manifestoes have been categorized in four groups: those that do not mention immigration; those that mention immigration in neutral terms (mostly, very briefly); those that frame the effects of migration positively (identifying positive cultura1/demographic or economic effects); and those that frame such effects negatively (identifying negative effects on public security, economy, culture) ${ }^{7}$.

Table 1. Number of Electoral Manifestos that mention Immigration - Regional Elections of November 2017.

\begin{tabular}{|c|c|c|c|c|}
\hline & $\begin{array}{l}\text { Immigration or } \\
\text { asylum not } \\
\text { mentioned in the } \\
\text { electoral } \\
\text { manifesto }\end{array}$ & $\begin{array}{l}\text { Manifestoes that } \\
\text { frame the effects } \\
\text { of migration } \\
\text { positively } \\
\text { (multicultural } \\
\text { frames, positive } \\
\text { economic effects) }\end{array}$ & $\begin{array}{l}\text { Manifestoes that } \\
\text { frame the effects } \\
\text { of migration in } \\
\text { neutral terms } \\
\text { (governance } \\
\text { frames) }\end{array}$ & $\begin{array}{l}\text { Manifestoes that } \\
\text { frame the effects } \\
\text { of migration } \\
\text { negatively } \\
\text { (negative effects } \\
\text { on public } \\
\text { security, } \\
\text { economy, culture) }\end{array}$ \\
\hline $\begin{array}{l}\text { Presidential } \\
\text { Candidates } \\
\text { (coalition in } \\
\text { parenthesis) }\end{array}$ & $\begin{array}{l}\text { N. Musumeci } \\
\text { (centre-right) }\end{array}$ & $\begin{array}{l}\text { F. Micari } \\
\text { (centre-left) } \\
\text { G. Fava } \\
\text { (left) }\end{array}$ & $\begin{array}{c}\text { G. Cancelleri } \\
\text { (M5S) }\end{array}$ & \\
\hline
\end{tabular}

${ }^{6}$ Local elections in Sicily were held in 137 municipalities. This sample includes all provincial capitals where elections were held and a representative number of towns and villages, selected to keep a balance between geographical areas, number of inhabitants and asylumseekers hosted, type of reception centres.

${ }^{7}$ Frames have been identifying consistently with Helbling's typology (2014). 
Table 2. Number of Electoral Manifestoes that mention Immigration - Local Elections of June 2018 (in bold: municipalities that host reception centres; in Italics: municipalities that host SPRAR centres ${ }^{8}$ ).

\begin{tabular}{|c|c|c|c|c|c|c|}
\hline & & $\begin{array}{l}\text { Number of } \\
\text { Mayoral } \\
\text { Candidates }\end{array}$ & $\begin{array}{l}\text { Manifestoes } \\
\text { that do not } \\
\text { mention } \\
\text { immigration }\end{array}$ & $\begin{array}{l}\text { Manifestoes } \\
\text { that frame the } \\
\text { effects of } \\
\text { migration in } \\
\text { neutral terms } \\
\text { (governance } \\
\text { frames) }\end{array}$ & $\begin{array}{l}\text { Manifestoes } \\
\text { that frame the } \\
\text { effects of } \\
\text { migration } \\
\text { positively } \\
\text { (multicultural } \\
\text { frames, } \\
\text { positive } \\
\text { economic } \\
\text { effects) }\end{array}$ & $\begin{array}{l}\text { Manifestoes } \\
\text { that frame } \\
\text { the effects } \\
\text { of migration } \\
\text { negatively } \\
\text { (negative } \\
\text { effects on } \\
\text { public } \\
\text { security, } \\
\text { economy, } \\
\text { culture) }\end{array}$ \\
\hline \multirow{5}{*}{ 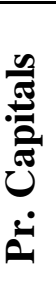 } & Messina & 5 & 1 & 2 & 2 & 0 \\
\hline & Catania & 5 & 4 & 0 & 1 & 0 \\
\hline & Siracusa & 7 & 3 & 2 & 1 & 1 \\
\hline & Ragusa & 7 & 5 & 0 & 1 & 1 \\
\hline & Trapani & 5 & 4 & 0 & 0 & 1 \\
\hline \multirow{4}{*}{$\stackrel{y}{0}$} & Modica $(\mathrm{RG})$ & 4 & 1 & 1 & 1 & 1 \\
\hline & $\overline{M a s c a l u c i a(C T)}$ & 4 & 3 & 0 & 1 & 0 \\
\hline & Carlentini $(S R)$ & 5 & 5 & 0 & 0 & 0 \\
\hline & Taormina (ME) & 3 & 3 & 0 & 0 & 0 \\
\hline \multirow{6}{*}{ 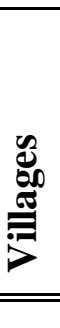 } & Valderice $(T P)$ & 3 & 3 & 0 & 0 & 0 \\
\hline & Santa Domenica (ME) & 2 & 2 & 0 & 0 & 0 \\
\hline & Francofonte $(\mathrm{SR})$ & 4 & 3 & 1 & 0 & 0 \\
\hline & Acate $(R G)$ & 3 & 0 & 2 & 0 & 1 \\
\hline & Mineo (CT) & 3 & 3 & 0 & 0 & 0 \\
\hline & TOTAL & 60 & 40 & 7 & 7 & 6 \\
\hline
\end{tabular}

The analysis reveals that most manifestoes, particularly in towns and villages, do not mention immigration or use neutral frames. This, despite most of the selected municipalities hosting reception centres for asylum-seekers directly managed by local governments (so-called SPRAR centres). Even in Mineo, the village with the biggest reception centre in Europe, none of the manifestoes advocates closure or partial emptying of the centre. Furthermore, in the five provincial capitals, seven centre-left or

\footnotetext{
${ }^{8}$ SPRAR stands for 'System for the Protection of Asylum-Seekers and Refugees'.
} 
independent candidates frame the effects of migration in positive terms. Only six mayoral candidates, all supported by the Lega, frame its effects negatively: they are mostly marginal candidates, none of whom was elected. The Lega thus emerges as the only party that attempts to inject anti-migrant frames into the electoral debate.

These findings are confirmed by the analysis of the media interviews released by the main Sicilian party leaders. Both the right-wing President of the Region Nello Musumeci, close to FdI, and the President of the Regional Council and leader of the centre-right Forza Italia Gianfranco Micciché never adopted anti-migrant frames and even expressed pro-migrant positions (Rossini, 2019; Reale, 2018). Remarkably, the mayor of Mazara del Vallo (the most important town then governed by the centre-right coalition) became known as a strong advocate of multiculturalism and crossMediterranean connections despite being affiliated to the radical right FdI (Giglioli, 2017). The two main leaders of the Lega in Sicily, Angelo Attaguile and Alessandro Pagano occasionally expressed in public anti-migrant positions (Il Fatto Quotidiano, 2017).

Conversely, the independent mayors of Palermo and Messina and the centre-left mayor of Catania all released several public interviews, to regional, national and international newspapers, in which they framed immigration in positive terms and invoked for the protection of migrants' rights (Ellyatt \& Marx, 2018; Gurrado, 2018; Pucciarelli \& Fraschilla, 2018; Van der Zee, 2017). They often reported to local media about invitations they received to give speeches about the migration crisis and Sicily's welcoming culture at foreign institutions and universities (Normanno, 2018). Before the municipal elections, its mayor Leoluca Orlando asked the competent national authorities 
to start using the port of the city to land rescued migrants and personally welcomed them in the port (van der Zee, 2017).

The expert interviews confirm that immigration was not a widely debated issue in recent local, regional and national electoral campaigns. Most of the interviewees stated that they could not remember any public statement on immigration during such campaigns, with the only exception of some progressive candidates in the main cities. Two interviewees reported that during the final rally of his campaign in 2017 , Leoluca Orlando declared that 'whoever lives in Palermo is a Palermitan citizen, no matter where he comes from'. Furthermore, experts struggled to identify clearly the positioning of parties in Sicily on immigration. As the director of a local research centre interviewed puts it:

The political debate on immigration in Sicily is messy, it's not possible to identify clear differences in party approaches to immigration. You can find a left-wing local government that is hostile towards migrants and open-minded mayors from Fratelli d'Italia (Director of a local research centre).

Importantly, while the Lega's attempts to politicise immigration are perceived as a shock to the system by some interviewees, others play down their effects:

The Sicilian leaders of the Lega are not conveyors of the typical ideas of the Lega on immigration, they are old politicians coming from other parties (...). If you speak with them or read what they say, you'll never find any public statement about migration (Deputy Prefect).

To conclude, the analysis opens up two key questions: why is it that most Sicilian party actors, including right-wing actors, do not politicise the immigration issue? And why do mayors of the main provincial capitals and port towns act as issue entrepreneurs (Hobolt \& De Vries 2015, p. 1161), actively politicising a previously ignored issue? 


\section{Sensemaking Processes.}

To address these questions, in this section I examine how Sicilian party actors made sense of immigration during the refugee crisis and defined their politicisation strategies on migration-related issues, mostly relying on insights derived from the 27 semistructured interviews. Consistently with Bird and Osland's framework (2010), I initially analyse actors' 'frames in thought', i.e. how the political actors interviewed understand the effects of migration in their environment (the first stage of the sensemaking process: 'framing the situation'). Through such analysis, in the first subsection that follows, three main groups of actors are identified. In the subsections that follow, I examine how these three groups of actors enact their understandings, i.e. how they establish 'what they should do next' (the second stage of the sensemaking process: 'making attributions') and how, based on the frames established and the attributions made, they establish the script that guides their actions (the third stage of the sensemaking process).

\section{Frame Analysis}

While 'frames in communication' focus on the aspects of an issue emphasized in elite discourse, 'frames in thought' focus on 'an individual's (cognitive) understanding' of a given situation. They relate to the dimensions or aspects of an issue that individuals think are most important, and guide their processing of information, affecting their evaluations (Druckman, 2001, p. 228; Chong and Druckman, 2007, p. 105). To identify these cognitive frames, I have asked questions investigating actors' perception of the effects of recent migration flows in their municipality and/or region. Findings of a frame analys is of actors' responses are illustrated in Table 3, based on a typology of frames derived from Helbling (2014, p. 25) and Dekker and Scholten (2017). 
Table 3. Frame Analysis: How Interviewees Frame the Effects of Immigration on their Region (RR= radical right; $\mathrm{CR}=\mathrm{centre-right;} \mathrm{CL}=\mathrm{centre-left}$; M5S=Movimento Cinque Stelle; IND=independent). In bold: mayors or deputy mayors; in Italics: actors from provincial capitals.
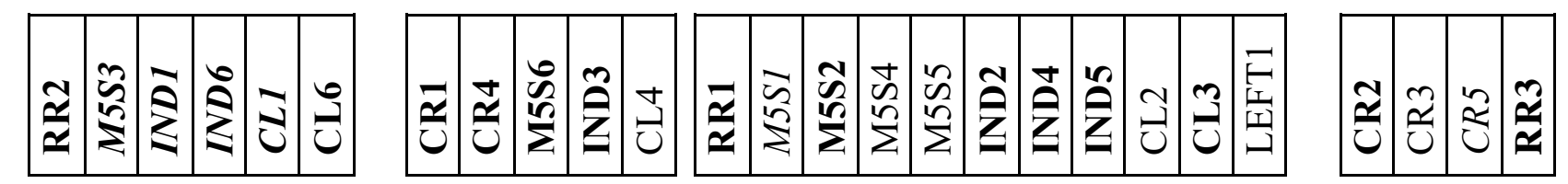

\begin{tabular}{|c|c|}
\hline \multirow{2}{*}{$\begin{array}{l}\text { Securitised/ } \\
\text { Threat frames }\end{array}$} & $\begin{array}{c}\text { Immigration as threat to law and } \\
\text { order }\end{array}$ \\
\hline & $\begin{array}{c}\text { Immigration as threat to public } \\
\text { health }\end{array}$ \\
\hline \multirow{2}{*}{$\begin{array}{l}\text { Economic } \\
\text { Frames }\end{array}$} & $\begin{array}{l}\text { Negative economic effects (labour } \\
\text { and public finance) }\end{array}$ \\
\hline & Positive economic effects \\
\hline \multirow{2}{*}{$\begin{array}{l}\text { Administrative } \\
\text { Frames }\end{array}$} & Burden for local authorities \\
\hline & $\begin{array}{l}\text { Corruption and Mismanagement of } \\
\text { the Reception System }\end{array}$ \\
\hline No effect & No significant effects \\
\hline \multirow{2}{*}{$\begin{array}{l}\text { Cultural or } \\
\text { Demographic } \\
\text { Effects }\end{array}$} & Positive socio-cultural effects \\
\hline & Negative socio-cultural effects \\
\hline
\end{tabular}
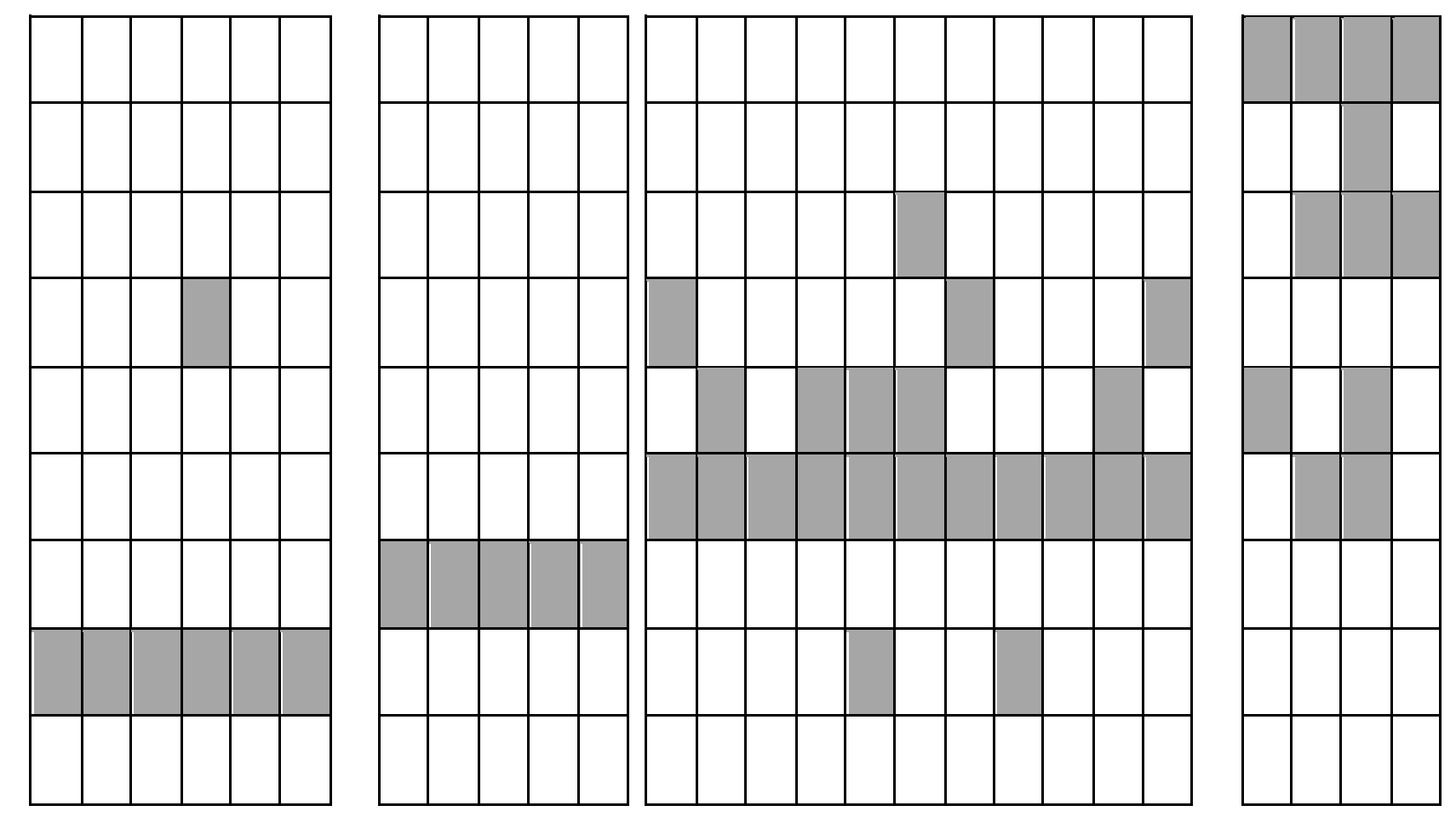
The table shows that actors' 'frames in though' are often related to the 'frames in communication' identified in the previous section. Six mayors and deputy mayors of provincial capitals or port towns adopt multiculturalist frames, describing the effects of migration in very positive terms. Most actors either do not identify any significant effect or adopt 'administrative frames' - mainly focusing on the inefficient management of asylum-seekers' reception - refusing to frame the effects of migration per se in negative or positive terms. Five centre-right or radical right actors, finally, adopt securitised or threat frames and describe the effects of migration in negative terms, although, when asked about the position they adopted during recent electoral campaigns, they all replied that the issue was not at the core of their campaign. Analyses of local media and of their social media pages confirmed that they did not speak about immigration in public. Importantly, the vast majority of interviewees, across all these three groups of actors, while replying to these questions, kept referring to public opinion to support their assessments of the effects of migration as positive or negative.

In the next paragraphs I focus on these three groups of actors and analyse how they enact their understandings.

\section{Why do mayors of the main cities and port towns act as issue entrepreneurs?}

The decision of mayors of the main Sicilian cities and port towns to actively politicise immigration through the adoption of pro-migrant stances, I argue, is largely driven by how they perceive the Sicilian public opinion as 'welcoming' towards migrants. Furthermore, it shows that these understandings of public opinion are embedded in an overarching narrative about public attitudes to immigration in Sicily, which is powerfully influenced by pre-existing inclusive identity-processes grounded on 'preconceptions about Sicilian tolerance' (Cole, 1997, p. 101). 
While replying to questions designed to grasp how they made sense of the refugee crisis, most Sicilian interviewees referred to at least one of three interconnected elements that influenced their assessments of 'what they should do next' (i.e. the attributions they made of the situation). First, Sicily's multicultural past and its position at the crossroads of Mediterranean history:

I think what determined Sicily's response [to the crisis] is its history and culture, which is built on the capacity to open itself up to the world outside. Sicily is at the centre of the Mediterranean, it couldn't be different (Deputy Mayor, PD).

Second, the defining experience of nearly a century of emigration from the region:

I'm clearly influenced by the fact that I have relatives that have been migrants. Initially they had harsh troubles (...), I know what 'reception' meant to them. Therefore, it's very easy for me to understand the reasons why these migrants come here...they are forced to. We have been a people of migration too (Mayor, PD).

In particular, at least four interviewees suggest that the experience of stigmatization endured by Southern Italians in Northern Italy necessarily fostered a compassionate understanding for asylum-seekers:

Especially in Northern Italy, we Sicilians have suffered what asylum-seekers are suffering now. Until a few years ago, in Bolzano they didn't rent houses to Sicilians, even if they had a job and were nice people (MP, centre-left).

Third, the tolerance of the local population towards migration, supposedly connected to the Sicilian history and culture:

Sicilians have always been super welcoming, because of their history and culture, they are used to share their land with other populations and they are open to 
different cultures (...), which explains why recent migration flows have not been really suffered here (MP, M5S).

We Sicilians are the product of migration flows to this island, across all the dominations that we experienced in history. Therefore, we are ready for asylumseekers' reception and we believe in multiculturalism (Deputy Mayor, Independent).

This prevailing idea of 'Sicilian tolerance' is also proposed in public speeches by right-wing actors, including the Sicilian President Musumeci (Rossini, 2018) and the right-wing mayor of Mazara del Vallo (Svampa, 2017). Importantly, this is often contrasted with the intolerance of Northern Italians and the concentration of antiimmigrant politics in the North:

I remember a meeting with other mayors [from Northern Italy]. They talked about solidarity but then 20 asylum-seekers were sent to a big city in the North and they raised hell. Here, we have put the se principles into practice (Deputy Mayor, PD).

Importantly, these accounts are at odds with existing data on public attitudes to immigration and rather, I argue, are connected with pre-existing conceptions of Sicilians' attitudes to immigration and a prevailing narrative on 'Sicilians' tolerance', already identified by Cole (1997, p. 101), in an ethnographic study conducted in the 1990s. According to this narrative, Sicily's history and culture and the long experience of emigration explained the acceptance of migrants in the region 'or should justify such acceptance if it did not already exist' in the eyes of the Sicilian political elite. The analysis conducted confirms that many Sicilian party actors, recalling the emigrant experience and the history of Sicily, ground the acceptance of migrants in historical precedent and give 'local resonance to abstract formulations of anti-racism and diversity' (ibid., p. 132). A 'satisfying' and 'insinuating' narrative, in Cole's words, 
‘emerges from a fusion of ideologies' and powerfully influences decision-making processes.

These dynamics seem consistent with well-established findings in the sensemaking literature: following Weick, sensemaking is retrospective, and grounded in identity construction, while identity is often shaped by interactions with others, and can 'turn out to be an issue of plausibility rather than accuracy' (Weick, Sutcliffe \& Obstfeld, 2005, p. 416). Sicilians' eagerness to compare oneself favourably with the North to address and avenge unjust treatment and characterizations particularly shows how positions on immigration in Sicily develop 'in relation to internal forms of “othering"' (Giglioli, 2017, p. 749) and as a reaction to 'anti-southernism in Italian politics and culture' (Cole, 1997, p. 101).

While this narrative about 'Sicilian tolerance' emerges in interviews with many different actors, it is mainly enacted by mayors of the main Sicilian cities and port towns, powerfully influencing their stances on migration and politicisation strategies. This seems to be due to the fact that, in the case of city mayors, several focusing events, indicators and personal experiences, provide positive feedback that reinforces preexisting perceptions and/or offer the moral basis for the enactment of this narrative on 'Sicilian tolerance' in the present (Kingdon, 2014, p. 113).

One of these indicators is the presence of a very active civil society, in big cities, which continuously invocates Sicilian culture and history with the aim to make more evocative their general calls for solidarity towards migrants. As Bassi explains (2014, p. 62), in a context where most party-actors refrain from politicising migration, the Sicilian politics of migration is mainly left to associations, NGOs and Christian churches, which contribute to provide a distorted idea of 'the public'. Furthermore, as 
four city deputy mayors admit, these NGOs created significant (and, sometimes, uncomfortable) pressures to which they had to respond:

We had to deal with the opposition of the Lega (...) but, even more, with promigrant activists, for whom the administration was not doing enough for the asylum-seekers. Sometimes they had very destructive attitudes, they think public institutions must be contrasted regardless of what they are doing (...). I could perceive a strong competition between them, and all of them tried to be in the limelight (Deputy Mayor, Independent).

A personal experience that powerfully shapes these actors' attributions is, then, the direct involvement in migrants' landing and the burial of dead migrants' bodies, described by these interviewees as very shocking events:

It was really heart-breaking, after that I thought that none of us can choose the place where we were born...therefore how can we not receive these people? (Deputy Mayor, M5S).

Finally, some strategic considerations contribute to lead actors to adopt proactive politicisation strategies, enacting the narrative on 'Sicilian tolerance'. Without constraints from public opinion, these mayors perceive the refugee crisis as an opportunity to develop pro-migrant discourses that are strategically aimed at 'branding difference', promoting a new image of their cities and attracting attention from foreign institutions and media. A PD Deputy Mayor explains that 'the refugee crisis is an opportunity for Sicilian cities, to show their capacity to be open to the world, and to be an example for others'. The Mayor of Mazara del Vallo started to celebrate the multicultural status of the town with the aim to rebrand it as a tourist destination and strategic location for cross-Mediterranean relations (Giglioli, 2017, p. 758). The Mayor of Palermo, interviewed by CNBC, declared that 'there is no city in the world that 
changed so deeply and widely like Palermo (...) we were the capital of mafia, we are now the capital of human rights' (Ellyatt \& Marx, 2018).

\section{Why do most actors adopt strategies of issue avoidance?}

Table 3 shows that most interviewees (outside the main cities) do not frame the effects of migration in positive or negative terms. These ambiguous stances, I argue, are revealing of Hall's concept of 'deliberate malintegration' (1984): actors involved in designing migration policies - which are often the object of a range of competing interests - tend to develop strategies that are reflective 'of an intentional jumble, or ‘fudging', of different goals and priorities' (Geddes \& Boswell, 2011).

Again, the interview material reveals that understandings of public attitudes to immigration powerfully shape and influence these ambiguous strategies. Local public opinion, in Sicilian towns ${ }^{9}$ and villages, is mostly perceived by these interviewees as divided into two groups. Part of the population is perceived to be non-sympathetic or hostile to migrants, because of the perceived competition in the bottom of the labour market or under the influence of national media campaigns. Locals are reported to complain that immigrants receive the government attention that they also deserve but cannot get. Importantly, most of the interviewees, however, explain that this opposition very rarely ends up in open protests or violence.

Another part of the population, conversely, is perceived by these actors to be supportive or tolerant towards migrants' reception for ideological or religious reasons (the narrative on 'Sicilian tolerance') or because of the opportunities of business or

\footnotetext{
${ }^{9}$ These exclude the main port towns (see previous paragraph).
} 
employment offered by asylum-seekers' reception, which in bigger and wealthier cities are less noticed. As a mayor explains:

Asylum-seekers reception became an opportunity for several service providers (...) and its importance for the local economy has increased. I don't think this should represent a local development model for this province, but certainly this is now a sector of the economy that can offer some responses to a very high unemployment (Mayor, right-wing).

These different pressures shape actors' attributions of the situation around them, producing an enduring tension between, on the one hand, the opportunity to offer employment to locals and, on the other, the fear of hostile reactions by some groups of locals:

Accepting or not a reception centre is a difficult choice. This sector clearly created job opportunities that we didn't have before (...) and we had an increase of highskilled labour demand thanks to the reception centres. Yet, probably we had job losses in agriculture, since many asylum-seekers are exploited by local employers (Mayor, M5S).

In Mineo, harsh tensions developed between citizens who benefitted from the presence of the huge reception centre - which offered jobs to hundreds of locals, in an economically depressed area - and those complaining because of the problems of law and order that the centre created. In such a situation - and despite forensic evidence that members of the Rome-based gang 'Mafia Capitale' had infiltrated the management of the centre - none of the three mayoral candidates at the 2018 election included in the manifesto any significant statement on the refugee centre, and rather explained that the local administration has no competences on its management.

In other areas these underlying tensions remained more latent, leading mayors to make decisions on the creation of reception centres and their positioning on the issue 
more broadly by balancing the pressures and interests at stake. Sometimes, when they perceived a strong opposition by locals, they decided to oppose the creation of reception centres. More often, they accepted or informally promoted their creation, being very careful not to make the choice appear something that is openly decided upon and entails responsibility. Some interviewees from the civil society suggest that these decisions are significantly influenced by the possibility that reception centres offer to develop new patronage relationships.

To sum up, these actors' ambiguous stances and strategies of issue avoidance are linked to their perception of these competing interests. As a regional MP explains:

Immigration is a very slippery slope, when you openly speak about this topic, you disappoint some and you please others. Therefore, typically, you tend not to take side, or you only refer to the national level (...). Nobody speaks about that, because you can be perceived as a racist or as somebody who takes care of migrants rather than poor Sicilians (Regional MP, M5S).

\section{Why potential anti-migrant political entrepreneurs do not politicise the immigration issue?}

Finally, the case of those actors affiliated to centre-right or radical right parties that frame the effects of migration in securitarian terms but do not politicise migration, suggests that problem recognition is not sufficient by itself to place an item on the agenda. As Kingdon (2014, p. 114) explains, problems abound and decision-makers 'pay serious attention to only a fraction of them', while several considerations independent of problem-solving prompt politicians to act or not, including attempts to 'cast about ways to make their mark' or interest group pressure.

These actors mostly perceive locals to be harshly hostile to migrants and tend to dismiss the importance of asylum-seekers' reception in the local economy. As a centreright MP explains, 'our traditional attitude to welcome those who are suffering has 
turned into widespread racist and xenophobic attitudes'. Other elements explain their passive stances.

First, the way these actors make attributions about the situation around them is influenced by the lack of anti-migrant protests, which leads them to underestimate the salience of immigration. These interviewees are convinced that the widespread antimigrant sentiments they perceive are unlikely to generate protests or gain political expression, influencing people's voting, supposedly driven by other more salient issues. As a centre-right MP explains:

Clearly, it's important to coordinate a strict opposition to any attempt to increase migration flows to our region, but we cannot transform local electoral campaigns into a struggle around an issue which is marginal (MP, centre-right).

Second, these actors are afraid of the negative consequences that using antimigrant frames publicly might have on the Sicilian electorate. The catholic religion is depicted by most centre-right politicians as a foundational element of the Sicilian identity and, as many interviews suggest, constraints them, leading them to think that adoption anti-migrant stances is not politically convenient. As a centre-right MP admits, 'it is hard to say openly the things I tell you, because if you do so you are butchered in the local media'. Right-wing actors, in other words, perceive Sicilians to be sensitive to a strong 'antipopulist norm that dictates that politicians should not seek to exploit racial, ethnic or immigration-related fears in order to win votes' (Freeman, 1995, p. 885).

Third, the politicisation strategies adopted seem to be influenced by some interest group pressure. Conservative parties are traditionally close to the Sicilian economic elite and landowners, who often employ migrants in low-paid jobs (Corrado et al., 2018). Many right-wing interviewees mentioned, during the interview, that they 
personally employed some asylum-seekers in their farms or factories. As a right-wing mayor explains:

It is very common here to employ non-EU migrants in houses and enterprises, permanently or seasonally. They are employed not only to carry out tasks that locals don't want anymore, but also because they do it better, with higher dedication and greater punctuality, and certainly, on average, at a lower cost for employers (Mayor, right-wing).

In sum, the absence of anti-migrant protests - together with the strong Catholic identity and the close links between the conservative political elite and the economic elite - prevents the emergence of anti-migrant political entrepreneurs. Importantly, the opposite seems also true, as Figure 4 shows. Actors' strategic decisions not to politicise migration prevent the emergence of anti-migrant protests and the perceived absence of social mobilisations reinforces preconceptions of Sicilians' tolerance, representing a powerful 'feedback that gives information on current performance' (Kingdon, 2014, p. 113). Many interviewees, if explicitly asked so, reported that they remembered some spontaneous anti-migrant protests. These protests, however, received no support by the local political elites and did not gain significant media coverage, unlike in other regions (Pettrachin, 2019). In Kingdon's words (2014, p. 113) focusing events are important in influencing problem assessment but, in order to generate actions, 'need accompaniment in the form of pre-existing perceptions which they reinforce, firmer indicators, or combinations with other such events'. 
Figure 4. The non-politicisation of immigration outside the main Sicilian cities.

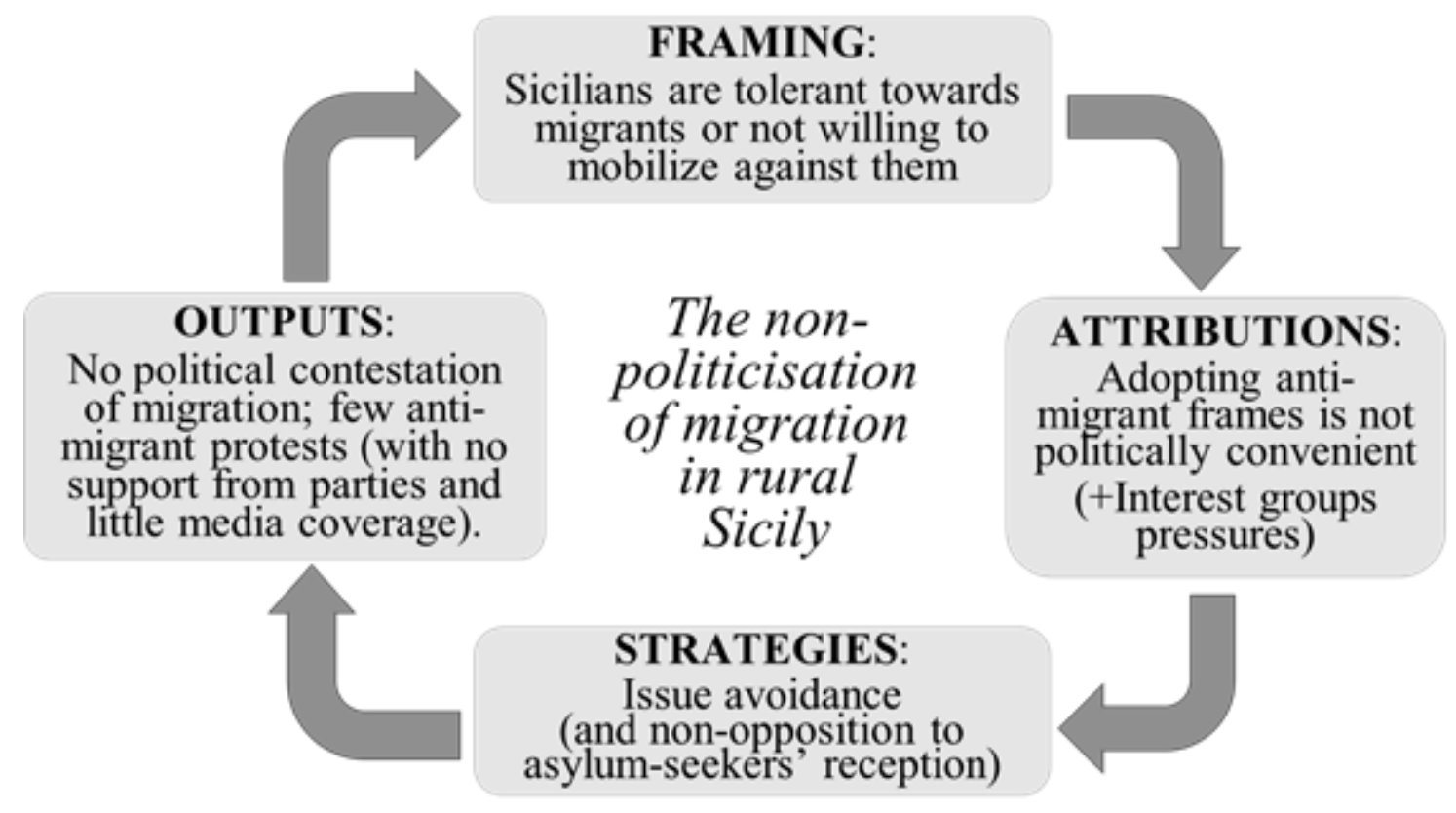

\section{Conclusion.}

This article has complemented findings of the existing literature on the drivers of party actors' politicisation strategies. This scholarship had so far largely ignored the reasoning of political actors to conclude that proactive politicisation strategies are a (necessary or very likely) outcome of increasing migration flows, issue salience, antimigrant attitudes and issue entrepreneurship of other right-wing parties (Hepburn, 2014; Grande, Schwarzbözl \& Fatke, 2018; Van der Brug, D’Amato, Ruedin, \& Berkhout, 2015). Rather than examining objective factors that are assumed to drive politicisation strategies, this paper has opened the 'black box' of party actors' decision-making, looking specifically at party elites' understandings and sensemaking processes.

The analysis of the Sicilian case has shown, first, that it is not self-evident that increases in migration flows and issue salience initiate reactive responses by subnational party actors which lead to high levels of politicisation of migration. As Cohen, March 
and Olsen explain (1972, p. 16), the relationship between problems and solutions is not necessarily smooth-flowing. This is not to say, clearly, that we should always expect a radical disconnect among flows, public reactions and actors' politicization strategies but, rather, to make the point that a mere focus on objective and measurable outcomes can be insufficient to catch the complexity of actors' decisions to politicise or not the immigration issue. Sicily has been centrally affected by the refugee crisis and experienced an increase in the salience of immigration after 2012, in a context characterised by (increasingly more) negative public attitudes to immigration. Despite that, most party actors competing in local, regional and national elections, including radical right actors, do not politicise the immigration issue. The only issue entrepreneurs in the region are the mayors of the main cities who, adopting multiculturalist frames, promote a very unusual type of 'positive' politicisation of migration.

Secondly, the analysis has demonstrated that Sicilian party actors' decisions not to politicise the immigration issue are driven by their understandings of the effects of migration on underlying social systems and, particularly, on public opinion. Politicians are not 'passive recipients of information, but active choosers, interpreters and rationalizers' (Mutz, 2011, p. 12), and the way they frame problems and make attributions is not a mere straightforward assessment of facts. Rather, they form their understandings through a process of sensemaking that is influenced by events and cues that they pick up from their environment, past experiences, identity processes and social relations.

In the main Sicilian cities, the paper shows, evidence about public attitudes to immigration is strongly embedded in a narrative story: party actors' understandings of public opinion are powerfully influenced by preconceptions about 'Sicilian tolerance', 
i.e. the widespread idea that Sicilians are welcoming towards asylum-seekers, and that this acceptance is justified by Sicily's history and culture. These preconceptions, disconnected from the evidence of available opinion polls, but reinforced by several focusing events and personal experiences, powerfully shape assessments of 'what should be done next'. These frames and attributions lead city mayors to adopt radical pro-migrant narratives, aimed at responding to pressures coming from a very active civil society and at 'branding difference', promoting a new positive image of their cities abroad.

In smaller towns and villages, most party actors perceive locals to be divided between those who are welcoming towards asylum-seekers - including because of the economic interests linked to the increasing importance of asylum-seekers' reception in the stagnant economy - and those who are hostile. When making migration-related decisions they tend to balance the pressures coming from these two groups. Most mayors end up adopting ambiguous strategies: they accept the creation of new reception centres but avoid to discuss the immigration issue as much as possible. Right-wing party actors - the potential anti-migrant entrepreneurs - tend to give more attention to people's concerns. They, however, perceive the salience of the immigration issue to be very low. Voting decisions of locals who are hostile to immigration are perceived not to be driven by their anti-immigration attitudes. Conversely, the average, Catholic, Sicilian voter is perceived to be sensitive to a strong 'antipopulist norm' dictating that politicians should not exploit immigration-related fears to win votes (Freeman, 1995, p. 885). These attributions prevent these actors from publicly using anti-migrant frames.

Finally, this article has shown that sensemaking involves the active authoring of events and frameworks for understanding, as people play a role in constructing the very 
situations they attempt to comprehend (Maitlis \& Christianson, 2014, p. 58). During the sensemaking process individuals, enacting the environments they face in dialogues and actions, generate a new reality, which can then influence or constrain the sensemaking process itself (Helms Mills Thurlow \& Mills, 2010, p. 185). In Sicily, the absence of anti-migrant protests prevents the emergence of anti-migrant political entrepreneurs, but the absence of anti-migrant entrepreneurs also prevents the emergence of anti-migrant campaigning, representing a powerful feedback that reinforces preconceptions of Sicilians' tolerance.

\section{References.}

Abou-Chadi, T., \& Helbling, M. (2018). How Immigration Reforms Affect Voting Behavior. Political Studies, 66(3), 687-717.

Ambrosini, M. (2018). Irregular Immigration in Southern Europe. Actors Dynamics and Governance. Basingstoke: Palgrave Macmillan.

Ansa (2018, June). Salvini, stop Sicilia campo profughi Ue. Retrieved from: http://www.ansa.it/sicilia/notizie/2018/06/03/salvini-stop-sicilia-campoprofughi-ue_e0de11c0-e8d7-415d-9d3e-531dfcd3e009.html

AskaNews (2017, July). Migranti, Meloni (Fdi): il governo mette Calabria in ginocchio. Retrieved from: http//www.askanews.it/politica/2017/07/10/migranti-melonifdi-il-governo-mette-calabria-in-ginocchio-pn_20170710_00270/

Bale, T. (2008). Turning Round the Telescope. Centre-Right Parties and Immigration and Integration Policy in Europe. Journal of European Public Policy, 15(3), $315-330$.

Bassi, M. (2014). The Christian Support Networks for Immigrants in Palermo. Partecipazione e Conflitto, 7(1), 58-82.

Bevir, M., \& Rhodes, R. (2003). Governance Stories. London: Routledge.

Bird, A., \& Osland, J. (2005). Making Sense of Intercultural Collaboration. International Studies of Management and Organization, 35(4), 115-132.

Boswell, C., \& Geddes, A. (2011). Migration and Mobility in the European Union. Basingstoke: Palgrave Macmillan. 
Brunsson, N. (1985). The Irrational Organization: Irrationality as a Basis for Organizational Action and Change. New York: Wiley.

Caponio, T. (2005). Policy Networks and Immigrants Associations in Italy: The Cases of Milan, Bologna and Naples. Journal of Ethnic and Migration Studies, 31(5), 931-950.

Castelli Gattinara, P. (2016). The Politics of Migration in Italy: Perspectives on Local Debates and Party Competition. London: Routledge.

Cerruto, M., \& Raniolo, F. (2018). From Exchange to Voice. Voting in Southern Italy. Journal of Modern Italian Studies 23(4): 418-436.

Cochrane, A. (1998). Illusions of Power: Interviewing Local Elites. Environment And Planning 30(12): 2121-2132.

Cohen, M., March, J., \& Olsen, J. (1972). A Garbage Can Model of Organizational Choice. Administrative Science Quarterly, 17(1), 1-25.

Cole, J. (1997). The New Racism in Europe: A Sicilian Ethnography. Cambridge: University Press.

Corrado, A., Caruso, F. S., Lo Cascio, M., Nori, M., Palumbo, L. \& Triandafyllidou, A. (2018). Is Italian Agriculture a Pull Factor for Irregular Migration - and if so why? (Technical Report). Florence: European University Institute.

D'Angelo, A. (2019). Italy: the "Illegality Factory"? Theory and Practice of Refugee Reception in Sicily. Journal of Ethnic and Migration Studies, 45(12), 22132226.

De Giorgi, E., \& Tronconi, F. (2018). The Center-Right in a Search for Unity and the Re-Emergence of the Neo-Fascist Right. Contemporary Italian Politics, 10(4), 330-345.

Dekker, R., \& Scholten, P. (2017). Framing the Immigration Policy Agenda: A Qualitative Comparative Analysis of Media Effects on Dutch Immigration Policies. The International Journal of Press/Politics, 22(2), 202-222.

Dennison, J. (2018, April). Understanding Attitudes to Immigration in Italy Today. Paper presented at the Metropolis High-level Seminar, Florence.

Dennison, J. (2019). A Review of Public Issue Salience: Concepts, Determinants and Effects on Voting. Political Studies Review 17(4), 436-446.

Dennison, J., \& Geddes, A. (2019). A Rising Tide? The Salience of Immigration and the Rise of Anti-Immigration Political Parties in Western Europe. Political Quarterly, 90(1), 107-116. 
Dixon, T., Hawkins, S., Heijbroek, L., Juan-Torres, M., \& Demoures, F. (2018). Attitudes towards National Identity, Immigration and Refugees in Italy (More in Common Report). Retrieved from: https://www.moreincommon.com/ourwork/publications/

Dorussen, H., Lenz, H., \& Blavoukos, S. (2005). Assessing the Reliability and Validity of Expert Interviews. European Union Politics 6(3), 315-337.

Eckstein, H. (1975). Case studies and Theory in Political Science. In F. Greenstein, \& N. Polsby (Eds.), Handbook of Political Science (pp. 79-133). Reading, MA: Addison-Wesley.

Ellyatt, H., \& Marx, W. (2018, February). Ahead of Italy's Election, Immigration is Seen as a Key Issue on the Southern Island of Sicily. CNBC. Retrieved from: https://www.cnbc.com/2018/02/28/italy-election-immigration-is-seen-as-a-keyissue-in-sicily.html

Freeman, G. (1995). Modes of Immigration Politics in Liberal Democratic States. The International Migration Review, 29(4), 881-902.

Genovese, F., Belgioioso, M., \& Kern, F. (2016). The Political Geography of Migrant Reception and Public Opinion on Immigration: Evidence from Italy (Working Paper). Retrieved from: http://federicagenovese.com/downloads/GBK_itmigr_231017.pdf

Gianfreda, S. (2018). Politicization of the Refugee Crisis? A Content Analysis of Parliamentary Debates in Italy the UK and the EU. Italian Political Science Review, 48(1), 85-108.

Giglioli, I. (2017). From “A Frontier Land" to "A Piece of North Africa in Italy": The Changing Politics of "Tunisianness" in Mazara del Vallo. International Journal of Urban and Regional Research, 41(5), 749-766.

Gilligan, C. (2015). The Public and the Politics of Immigration Controls. Journal of Ethnic and Migration Studies, 41(9), 1373-1390.

Grande, E., Schwarzbözl, T., \& Fatke, M. (2018). Politicizing Immigration in Western Europe. Journal of European Public Policy, 26(10), 1444-1463.

Green-Pedersen, C., \& Krogstrup, J. (2008). Immigration as a Political Issue in Denmark and Sweden. European Journal of Political Research, 47(5), 610-634.

Green-Pedersen, C., \& Otjes, S. (2017). A Hot Topic? Immigration on the Agenda in Western Europe. Party Politics, 25(3), 424-434. 
Gurrado, A. (2018, August). Gli Arancini di Enzo Bianco. Il Foglio. Retrieved from: https://www.ilfoglio.it/band iera-bianca/2018/08/23/news/gli-arancini-di-enzobianco-210811/

Hall, P. (1984). The Patterns of Economic Policy: An Organizational Approach. In S.

Bornstein, D. Held, \& J. Krieger (Eds.), The State in Capitalist Europe (pp. 3153). London: Allen and Unwin.

Hay, C. (2002). Political Analysis. Basingstoke: Palgrave Macmillan.

Helbling, M. (2014). Framing Immigration in Western Europe. Journal of Ethnic and Migration Studies, 40(1), 21-41.

Helms Mills, J., Thurlow, A., \& Mills, A. (2010). Making Sense of Sensemaking: The Critical Sensemaking Approach. Qualitative Research in Organizations and Management, 5(2), 182-195.

Hepburn, E. (2014). Multilevel Party Politics of Immigration: Territorial Rescaling and Party Competition. In R. Zapata-Barrero, \& E. Hepburn (Eds.), The Politics of Immigration in Multi-Level States - Governance and Political Parties (pp. 4161). Basingstoke: Palgrave Macmillan.

Hobolt, S., \& de Vries, C. (2015). Issue Entrepreneurship and Multiparty Competition, Comparative Political Studies, 48(9), 1159-1185.

Hooghe, L., \& Marks, G. (2018). Cleavage Theory Meets Europes Crises: Lipset, Rokkan, and the Transnational Cleavage. Journal of European Public Policy, 25(1), 109-135.

Il Fatto Quotidiano (2017, September). Migranti, Nuovo Sindaco di Lampedusa: "Minacciano, Molestano, Rubano. Hotspot Va Chiuso". Nicolini: "Fa Terrorismo". Il Fatto Quotidiano. Retrieved from https://www.ilfattoquotidiano.it/2017/09/16/migranti-nuovo-sindaco-dilampedusa-minacciano-molestano-rubano-hotspot-va-chiuso-nicolini-faterrorismo/3860665/

Ivaldi, G., Lanzone, M.E., \& Woods, D. (2017). Varieties of Populism across a LeftRight Spectrum: The Case of the Front National, the Northern League, Podemos and Five Star Movement, Swiss Political Science Review 23(4), 354-376.

Iversen, T., \& Goplerud, M. (2018). Redistribution Without a Median Voter: Models of Multidimensional Politics. Annual Review of Political Science 21(1), 295-317. Kingdon, J.W. (2014). Agendas Alternatives and Public Policies. Essex: Pearson. 
Krosnick, J.A. (1990). Government Policy and Citizen Passion: A Study of Issue Publics in Contemporary America. Political Behaviour. 12, 59-92.

Maitlis, S. and Christianson, M. (2014). Sensemaking in Organizations: Taking Stock and Moving Forward. The Academy of Management Annals, 8(1), 57-125.

Manzano, R., Mishtal, J., \& Harris, S. (2018). The Effect of Second Reception Center Practices on Refugee Experiences in Sicily. Human Organization, 77(2), 79-89.

Marks, G., \& M.R. Steenbergen (2004). European Integration and Political Conflict. Cambridge: University Press.

Mastroianni, F. (2018, March). Come cambia l'Italia. Dove aumentano di più gli stranieri. Il Sole 24 Ore. Retrieved from: https://www.infodata.ilsole24ore.com/2018/03/09/cambia-litalia-aumentano-piugli-stranieri/.

Meyer, S., \& Rosenberger, S. (2015). Just a Shadow? The Role of Radical Right Parties in the Politicization of Immigration 1995-2009. Politics and Governance, 3(2), $1-17$.

Ministry of Interior (2018). Cruscotto Statistico al 30 Settembre 2018. Retrieved from: http://www.libertaciviliimmigrazione.dlci.interno.gov.it/sites/default/files/allegat i/cruscotto_statistico_giornaliero_30-09-2018_0.pdf.

Mudde, C. (2004). The Populist Zeitgeist. Government and Opposition 39(4), 542-563.

Mutz, D. (2011). Political Psychology and Choice. In R.E. Goodin (Ed.), The Oxford Handbook of Political Science (pp. 1-21). Oxford: University Press.

Normanno (2018, April). Arrival Cities: Accorinti e la Santisi a Bruxelles per Parlare di Messina come Modello dell'Accoglienza. Normanno.com. Retrieved from http://normanno.com/attualita/arrival-cities-accorinti-santisi-messina-modelloaccoglienza/

Odmalm, P., \& Bale, T. (2015). Immigration into the Mainstream: Conflicting Ideological Streams, Strategic Reasoning and Party Competition. Acta Politica, 50(4), 365-378.

Pettrachin A. (2019). Opening the Black Box of Asylum Governance: Decision-Making and the Politics of Asylum Policymaking. Italian Political Science Review. Advance online publication. doi:10.1017/ipo.2019.30

Pierre, J. (2000). Debating Governance. Oxford: University Press.

Pucciarelli, M., \& Fraschilla, A. (2018, June). De Magistris: "Il Porto di Napoli Pronto ad Accogliere i Migranti”. La Repubblica. Retrieved from 
https://www.repubblica.it/politica/2018/06/10/news/de_magistris_il_porto_di_n apoli_pronto_ad_accogliere_i_migranti_-198662406/

Reale, C. (2018, August). Diciotti, Miccichè contro Salvini: “Sei uno str...”. Cancelleri all'attacco: "Fi supera il Pd a sinistra". La Repubblica. Retrieved from https://palermo.repubblica.it/politica/2018/08/24/news/diciotti_micciche_contro _salvini_sei_uno_str_cancelleri_all_attacco_fi_supera_il_pd_a_sinistra_204799662/

Rossini, S. (2019, August). "Sì, Sono di Destra. Ma i Migranti li Chiamo Fratelli". Parla Nello Musumeci. LEspresso. Retrieved from: http://espresso.repubblica.it/palazzo/2018/08/24/news/si-sono-di-destra-ma-imigranti-li-chiamo-fratelli- 1.325912

Scheufele, D. (1999). Framing as a Theory of Media Effects. Journal of Communication, 49, 103-122.

Svampa, P. (2017). La Società Multietnica è il Primo Tassello di una Società Multiculturale. Libertà Civili, March/April.

Van der Brug, W., D’Amato, G., Ruedin, D., \& Berkhout, J. (2015). The Politicisation of Migration. London: Routledge.

Van der Zee, R. (2017, April). He Fought the Mafia and Won. Now this Mayor is Taking on Europe Over Migrants. The Guardian. Retrieved from: https://www.the guardian.com/global-development-professionalsnetwork/2017/apr/18/he-fought-the- mafia-and-won-now-this- mayor-is-takingon-europe-over-migrants

Vranceanu, A. (2017). The Impact of Contextual Factors on Party Responsiveness Regarding Immigration Issues. Party Politics, 25(4), 583-593.

Weick, K. (1995). Sensemaking in Organizations. Thousand Oaks: Sage.

Weick, K., Sutcliffe, K., \& Obstfeld, D. (2005). Organizing and the Process of Sensemaking. Organization Science, 16(4), 409-421.

Zapata-Barrero, R. (2009). Immigration and Self-government of Minority Nations. Brussels: Peter Lang. 


\section{Annexe}

Table 4. Sample of interviewees (14 expert interviews).

\begin{tabular}{|c|c|}
\cline { 2 - 2 } \multicolumn{1}{c|}{} & $N^{\circ}$ \\
\hline Deputy Prefects & 2 \\
Trade unions & 2 \\
Advocacy NGOs & 3 \\
Service Providers & 4 \\
\hline Experts & 2 \\
\hline Civil Servants (Regional/Local authorities) & 1 \\
\hline \hline TOTAL & $\mathbf{1 4}$ \\
\hline
\end{tabular}

Table 5. Sample of political actors interviewed disaggregated according to their political affiliation (27 semi-structured interviews).

\begin{tabular}{|c|c|c|}
\hline \multirow{2}{*}{ Radical Right } & Party & $N^{\circ}$ \\
\cline { 2 - 3 } & Fratelli d'Italia & 1 \\
\cline { 2 - 3 } & Lega (Noi con Salvini) & 1 \\
\hline \multirow{2}{*}{ Centre-Right } & DiventeràBellissima & 1 \\
\cline { 2 - 3 } & Forza Italia & 2 \\
\hline \multirow{2}{*}{ Centre-Left } & Nuovo Centrodestra & 3 \\
\cline { 2 - 3 } Left & Partito Democratico & 1 \\
\hline Movimento Cinque Stelle & I Verdi & 1 \\
\hline None & Articolo 1-MDP & 7 \\
\hline
\end{tabular}

Notes: the sample includes 19 mayors/deputy mayors of a mix of provincial capitals, towns and villages; two regional MPs; 6 national MPs. 